\title{
HUBUNGAN KEKUATAN OTOT LENGAN DENGAN KETERAMPILAN LAY UP SHOOT BOLABASKET
}

\author{
Ahmad Rahmadani \\ Universitas Islam Riau \\ Email: ahmadrahmadani@edu.uir.ac.id
}

\begin{abstract}
ABSTRAK
Penelitian ini merupakan penelitian kuantitatif dengan menggunakan metode survei. Penelitian ini bertujuan untuk mengetahui hubungan antara kekuatan otot lengan dengan keterampilan lay up shoot bolabasket. Sebelum melakukan penelitian terlebih dahulu dilakukan uji coba terhadap instrumen tes yang akan digunakan dalam penelitian. Uji coba ini dimaksudkan untuk mengetahui apakah instrumen yang akan diuji itu valid dan reliabel. Penelitian ini dilaksanakan di SMPN 9 Pekanbaru dengan jumlah sampel sebanyak 30 siswa yang mengikuti latihan bolabasket di sekolah. Dari hasil penelitian melalui hasil analisis data membuktikan bahwa: Terdapat hubungan yang positif antara kekuatan otot lengan dengan keterampilan lay up shoot bolabasket dengan kontribusi sebesar $61 \%$. Dengan demikian hipotesis yang diajukan terbukti bahwa variabel bebas mempunyai hubungan yang signifikan dengan variabel terikat.
\end{abstract}

Kata Kunci: Kekuatan, Bolabasket, Lay Up Shoot

\section{ABSTRACT}

This research is a quantitative research using survey method. This study aimed to determine the correlation between arm muscle strength with lay up shoot skill of basketball. Before conducting research trials conducted prior to the test instrument to be used in research. The trial is intended to determine whether the instrument to be tested was valid and reliable. The research was conducted in Junior High School 9 Of Pekanbaru with a total sample of 30 students who follow the practice basketball at school. From the results of analysis data prove that: There is a positive correlation between arm muscles strength with lay up shoot skill of basketball, contribute of $61 \%$. Thus the proposed hypothesis is proven that the independent variable have a correlation with the dependent variable.

Keywords: Strength, Lay Up Shoot, Basketball

\section{PENDAHULUAN}

Arus globalisasi dan perkembangan modern yang kian tidak terbendung dalam beberapa dekade belakangan ini membuat bangsa Indonesia harus mempersiapkan diri dalam menghadapinya. Salah satunya yaitu dengan meningkatkan kualitas sumber daya manusia. Untuk meningkatkan SDM, ada beberapa cara yang dapat dilakukan, diantaranya yaitu dengan meningkatkan mutu pendidikan dan memasyarakatkan olahraga. Kalau diperhatikan, olahraga merupakan salah satu wadah untuk meningkatkan sumber daya manusia. Dimana olahraga yang dilakukan secara teratur dan kontiniu akan dapat meningkatkan kualitas fisik dan mental yang berguna untuk pembentukan watak manusia yang mempunyai kepribadian, berdisiplin tinggi, memiliki sikap sportif. Ini semua pada akhirnya akan dapat meningkatkan produktivitas manusia itu sendiri. 
Selain meningkatkan kualitas fisik dan mental, olahraga juga dapat meningkatkan citra bangsa dan kebanggaan nasional dengan jalan pencapaian prestasi setinggi-tingginya. Untuk meningkatkan prestasi olahraga tersebut perlu digalakkan melalui perencanaan dan pelaksanaan yang terkoordinir, terorganisir yang dilakukan secara terpadu dan merata di seluruh tanah air, yang bukan saja dilaksanakan oleh pemerintah akan tetapi didukung juga oleh berbagai pihak. Hal ini bisa dilakukan dengan cara menyediakan sarana dan prasarana serta berusaha melakukan pembibitan dan pembinaan olahraga di masyarakat khususnya olahraga bolabasket.

Kalau kita lihat sekarang ini perkembangan terhadap pembinaan olahraga bolabasket sudah cukup bagus. Saat ini bolabasket menjadi salah satu cabang olahraga yang berkembang populer di tengah-tengah masyarakat. Penggemarnya berasal dari segala usia, mulai dari anak-anak, remaja, hingga dewasa baik pria maupun wanita memainkannya. Mereka merasakan bahwa permainan bolabasket adalah olahraga yang menyenangkan, mendidik, menghibur, menyehatkan, dan kompetitif. Karena itulah olahraga ini sudah menjadi hobi sosial di kalangan masyarakat.

Dengan semakin banyaknya pusat-pusat olahraga, dan semakin baiknya standar pendidikan jasmani serta semakin bertambah pula fasilitas-fasilitas olahraga di sekolahsekolah, tentu membuat olahraga ini semakin digemari semua orang. Bolabasket adalah olahraga untuk semua orang. Walaupun bolabasket adalah olahraga anak muda dengan pemain terbanyak pria remaja namun bolabasket dimainkan juga oleh pria maupun wanita dari segala usia dan ukuran tubuh bahkan oleh mereka yang cacat, termasuk yang duduk di atas kursi roda.

Bolabasket merupakan cabang olahraga yang makin banyak digemari oleh masyarakat terutama di kalangan generasi muda. Hal ini dapat dilihat dari semakin meningkatnya minat para pelajar mulai dari sekolah dasar, sekolah menengah hingga ke bangku perkuliahan yang berpartisipasi dalam kegiatan ekstrakurikuler bolabasket di sekolah maupun berlatih di klub-klub bolabasket. Selain itu perkembangan bolabasket juga didukung oleh banyaknya event-event pertandingan yang diselenggarakan secara reguler pada tingkat-tingkat umur tertentu, mulai dari yang berskala kecil, seperti: LIBALA untuk siswa SMP, HSBL dan DBL untuk pelajar SMA, LIBAMA untuk mahasiswa hingga Kompetisi NBL (National Basketball League) yang berskala nasional. Melalui kegiatan olahraga bolabasket ini para remaja banyak memperoleh manfaat khususnya dalam pertumbuhan fisik, mental, dan sosial.

Bolabasket adalah olahraga berkelompok yang terdiri dari dua tim yang beranggotakan masing-masing lima orang yang saling bertanding mencetak poin dengan memasukkan bola ke dalam keranjang milik lawan. Bolabasket sangat cocok untuk dimainkan karena bisa dilakukan di ruang terbuka dan di ruang tertutup dan hanya memerlukan lapangan yang relatif kecil. Selain itu, bolabasket mudah dipelajari karena bentuk bolanya yang besar, sehingga tidak menyulitkan pemain ketika memantulkan atau melempar bola tersebut.

Untuk dapat melakukan permainan bolabasket maka perlu penguasaan teknik dasar bolabasket yang baik, tekniknya meliputi dribble, passing, shooting. Teknik shooting merupakan yang dominan dan mempunyai peranan yang vital dalam permainan bolabasket. Sehingga wajar jika dalam pembelajaran bolabasket dijadikan fokus utama pembelajaran. Salah satu jenis shooting yang harus dilatih adalah lay up shoot. Menurut PERBASI (2006: 18), "Tembakan lay up adalah hal yang harus di 
pelajari dalam olahraga bolabasket. Dalam situasi persaingan, jenis tembakan ini harus biasa dilakukan pemain baik dengan tangan kanan maupun kiri". Teknik lay up shoot merupakan teknik yang sangan fundamental dalam permainan bolabasket. Karena poin yang dihasilkan dari lay up shoot merupakan yang tertinggi dibandingkan dari jenis shooting yang lain seperti free throw atau three poin shoot.

Menurut Vic Amber (2013: 33), "Lay up shoot merupakan tembakan yang paling aman dan paling efektif kalau pemain yang memegang bola tadi tidak dibayangi lawan".Untuk itu, diperlukan latihan yang panjang secara continue agar bisa menguasai keterampilan lay up shoot tersebut. Latihan merupakan faktor yang sangat penting dalam pencapaian prestasi yang maksimal. Ada beberapa aspek latihan yang diperlukan dan dilatih secara seksama oleh pelatih dan siswa untuk tercapainya prestasi maksimal, salah satunya adalah kondisi fisik. Menurut Nancy Lieberman (2012: 94), "The layup should be the first shot you master; it's a high-percentage shot".

Menembak, khususnya tembakan lay up merupakan keahlian yang sangat penting dalam bola basket disamping teknik dasar yang lain. Penembak yang baik sering disebut dengan pure shooter. Menurut Danny Kosasih (2008: 28), "Agar seorang pemain bisa menjadi shooter yang baik, pemain tersebut harus menikmati latihan shooting-nya sehingga pemain tersebut akan terus menerus melakukan latihan shooting dengan tidak mudah bosan". Dalam melakukan tembakan lay up sangat diperlukan adanya ketepatan dalam mengarahkan bola ke ring basket. Karena salah satu faktor yang menetukan untuk menghasilkan suatu tembakan yang akurat adalah sudut tembakan. Menurut Hall Wissel (2012: 99), "The layup shot is used near the basket after a cut or drive. To jump high on a layup, you must have speed on the last three or four steps of your cut or drive, but you must also control your speed".

Kondisi fisik adalah adalah salah satu prasyarat yang sangat diperlukan dalam setiap usaha peningkatan prestasi, bahkan dapat dikatakan sebagai titik tolak suatu olahraga prestasi. Dalam permainan bolabasket kondisi fisik yang prima sangat dibutuhkan baik itu untuk penguasaan teknik, melakukan teknik maupun dalam menjalankan taktik permainan. Kondisi fisik adalah salah satu kesatuan utuh dari komponen-komponen yang tidak dapat dipisahkan, baik peningkatannya maupun pemeliharaannya. Artinya bahwa setiap usaha peningkatan kondisi fisik, harus mengembangkan semua komponen kondisi fisik. Adapun komponen-komponen kondisi fisik tersebut meliputi: (1) kekuatan (strength); (2) daya tahan (endurance); (3) daya ledak otot (muscular power); (4) kecepatan (speed); (5) kelentukan (flexibility); (6) keseimbangan (balance); (7) koordinasi (coordination); (8) kelincahan (agility); (9) ketepatan (acuracy): dan (10) reaksi (reaction).

Kebutuhan akan komponen-komponen kondisi fisik bagi setiap cabang olahraga berbeda-beda sesuai dengan spesifik atau ciri khas cabang olahraga tertentu dan diarahkan kepada tuntutan bagi cabang olahraganya. Dalam permainan bola baske Kekuatan merupakan kompenen yang sangat penting dari kondisi fisik secara keseluruhan, karena merupakan daya penggerak setiap aktifitas fisik salah satunya adalah otot lengan. Kekuatan otot lengan merupakan salah satu faktor utama yang memberikan kontribusi maksimal terhadap keterampilan teknik dasar bolabasket. Seseorang yang memiliki kekuatan otot lengan yang prima tentunya memiliki kecenderungan lebih baik dalam menguasai keterampilan teknik dasar termasuk lay up 
shoot. Untuk itu latihan-latihan yang bisa meningkatkan kerja otot lengan harus diprioritaskan untuk menunjang keterampilan teknik dasar lay up shoot.

Kekuatan (strength) merupakan salah satu komponen dasar biomotor yang diperlukan dalam setiap cabang olahraga. Menurut Sukadiyanto (2011; 137), "Kekuatan secara umum adalah kemampuan otot atau sekelompok otot untuk mengatasi beban atau tahanan". Menurut Thomas R. Baechle (2008: 4), "At the most basic level, the strength and conditioning professional is concerned with maximizing physical performance and must therefore conduct programs that are designed to increase muscular strength, muscular endurance, and flexibility". Untuk dapat mencapai penampilan prestasi yang optimal, maka kekuatan harus ditingkatkan sebagai landasan yang mendasari dalam pembentukan komponen biomotor lainnya. Menurut Paavo V Komi (2008: 6), "The term strength will be employed to identify the maximal force or torque that can be developed by the muscles performing a particular joint movement (e.g. elbow flexion, knee extension)". Sasaran pada latihan kekuatan adalah untuk meningkatkan daya otot dalam mengatasi beban selama aktivitas olahraga berlangsung. Menurut Johansyah Lubis (2013: 68), "Kekuatan adalah kemampuan sistem neuromuscular dalam menghasilkan gaya/kekuatan untuk melawan tahanan dari luar". Oleh karena itu latihan kekuatan merupakan salah satu unsur biomotor dasar yang penting dalam proses mencetak olahragawan.

Berdasarkan pengamatan terhadap kegiatan klub ekstrakurikuler bolabasket yang ada di SMPN 9 Kota Pekanbaru, walaupun dalam penelitian ini tidak diarahkan untuk melihat perbedaan suatu keterampilan, tetapi secara kasat mata jelas terlihat adanya perbedaan tingkat dalam penguasaan keterampilan teknik dasar lay up shoot bolabasket. Ada yang sudah bagus, sedang, dan ada yang belum menguasai teknik lay up shoot secara optimal. Seperti terlihat ketika melakukan lay up shoot, banyak gerakan teknik yang tidak tepat sehingga tingkat akurasinya juga rendah. Terlihat juga tidak adanya koordinasi mata dan tangan dalam melakukan lay up shoot sehingga bolanya sering melenceng dari ring (airball). Kemudian ada juga bola hasil lay up shoot tidak sampai menyentuh ring. Ini bisa disebabkan karena siswa belum memiliki kekuatan otot lengan yang prima. Selain itu pelatih menerapkan latihan- latihan lay up shoot yang tidak bervariasi, akibatnya timbul rasa malas sehingga siswa tidak termotivasi lagi berlatih karena mengalami kebosanan.

\section{METODE PENELITIAN}

Berdasarkan kajian permasalahan yang akan diteliti dan tujuan yang akan dicapai, metode yang digunakan dalam penelitian ini adalah metode survey. Penelitian ini melibatkan variabel bebas yaitu kekuatan otot lengan dengan variabel terikat yaitu keterampilan lay up shoot bolabasket. Keterikatan antara variabel bebas dengan variabel terikat dalam penelitian ini dapat digambarkan dengan konstelasi sebagai berikut:

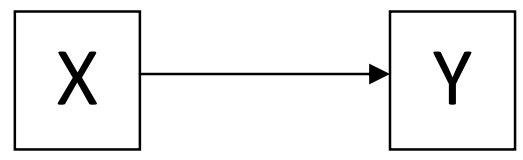

Gambar 1. Konstelasi Variabel Penelitian 
Keterangan:

$\mathrm{X}=$ Kekuatan Otot Lengan

$\mathrm{Y}=$ Keterampilan Lay Up Shoot

Penelitian ini dilaksanakan di SMP Negeri 9 Kota Pekanbaru. Sebelum penelitian terlebih dahulu dilakukan uji coba instrumen di SMP Islam 12 Al-Azhar Rawamangun. Waktu penelitian dimulai pada saat pengesahan judul penelitian dari tanggal 2 Oktober 2014 sampai mengambil data di lapangan yang berakhir pada tanggal 14 Januari 2015.

Populasi dalam penelitian ini berjumlah 30 siswa. Pengambilan Sampel dengan menggunakan total sampling. Menurut Sugiyono (2008: 124) Total Sampling adalah "Seluruh populasi dijadikan sampel penelitian". Penelitian ini menggunakan instrumen keterampilan lay up shoot diambil berdasarkan penilaian skor hasil dan proses. Kekuatan otot lengan menggunakan dynamometer. Analisis data untuk persyaratan uji analisis menggunakan uji normalitas, uji homogenitas, dan uji linearitas. Sedangkan untuk pengujian hipotesis penelitian menggunakan korelasi.

\section{HASIL DAN PEMBAHASAN}

Sesuai dengan permasalahan yang telah diuraikan, maka dalam bab ini akan dilakukan pemaparan dari hasil penelitian. Penelitian ini meliputi variabel terikat yaitu: keterampilan lay up shoot (Y), dan variabel bebas yaitu: kekuatan otot lengan (X). Data penelitian yang dideskripsikan adalah berkenaan dengan hasil pengukuran terhadap semua variabel tersebut. Berikut akan dijelaskan data yang diperoleh dari hasil penelitian.

\section{Data Lay Up Shoot}

Data keterampilan lay up shoot diperoleh dari skor proses dan hasil yang didapat saat testee melakukan tes lay up shoot. Ada lima sub dimensi yang dinilai yang menjadi hasil skor untuk mengukur keterampilan lay up shoot dan masing-masing sub dimensi diberi skor tiga, dua, dan satu. Dari hasil tes tersebut didapati nilai terendah adalah 32.11 , nilai tertinggi $=63.16$, rata-rata $=50.02$, median $=50.74$, modus $=63.16$, simpangan baku $=10.01$ dengan distribusi frekuensi dan histogram sebagai berikut.

Tabel 1. Distribusi Frekuensi Keterampilan Lay Up Shoot

\begin{tabular}{ccc}
\hline Skor & Fa & Fr \\
\hline $32-37$ & 4 & $13.33 \%$ \\
\hline $38-43$ & 4 & $13.33 \%$ \\
\hline $44-49$ & 5 & $16.66 \%$ \\
\hline $50-55$ & 6 & $20 \%$ \\
\hline $56-61$ & 6 & $20 \%$ \\
\hline $62-67$ & 5 & $16.66 \%$ \\
\hline Jumlah & $\mathbf{3 0}$ & $\mathbf{1 0 0 \%}$ \\
\hline
\end{tabular}




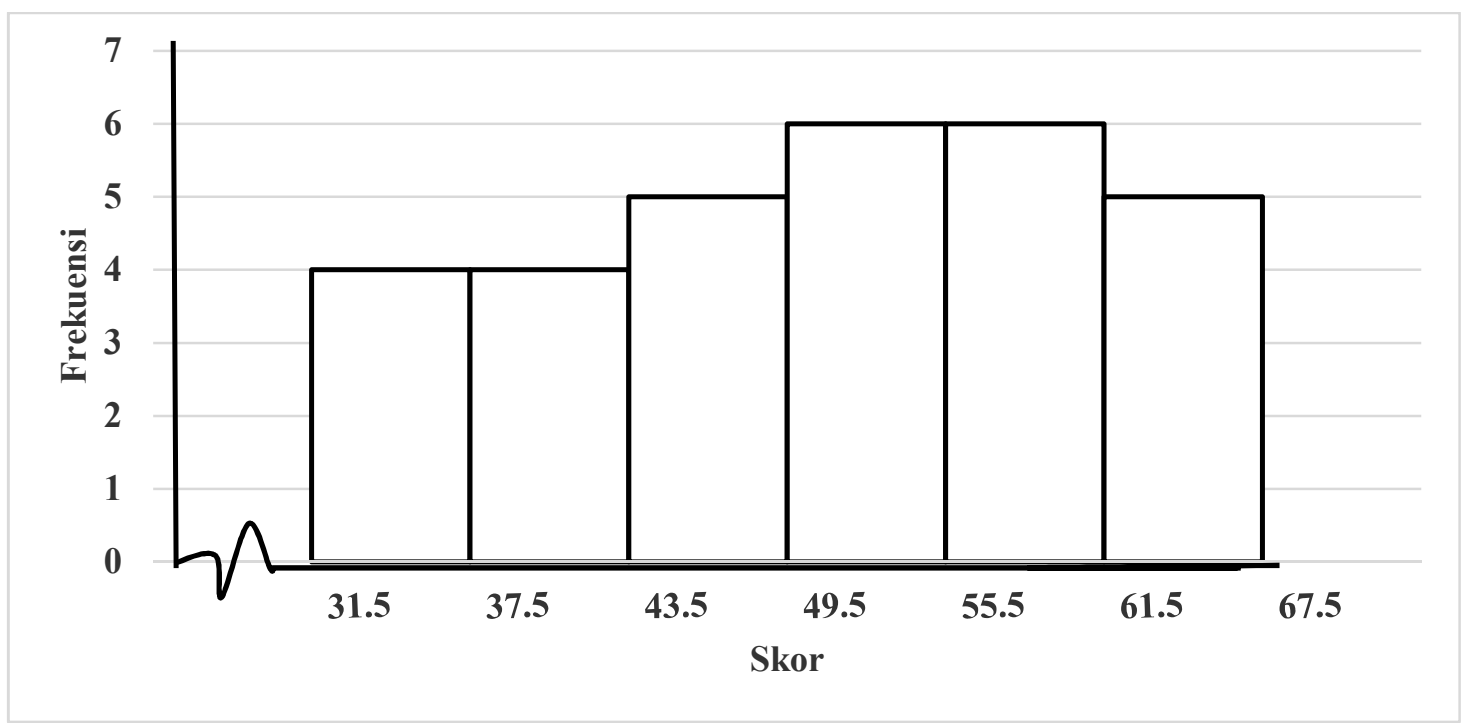

Gambar 2. Histogram Keterampilan Lay Up Shoot

\section{Data Kekuatan Otot Lengan}

Data kekuatan otot lengan diperoleh dari hasil pengukuran dengan menggunakan alat expending dynamometer. Data yang diperoleh dari hasil pengukuran tersebut adalah didapati nilai terendah $=9$, nilai tertinggi $=17$, rata-rata $=13.98$, median $=14.5$, modus $=14.5$, simpangan baku $=2.21$ dengan distribusi frekuensi dan histogram sebagai berikut.

Tabel 2. Distribusi Frekuensi Kekutatan Otot Lengan

\begin{tabular}{ccc}
\hline Skor & Fa & Fr \\
\hline $9.00-10.33$ & 3 & $10 \%$ \\
\hline $10.34-11.67$ & 2 & $6.66 \%$ \\
\hline $11.68-13.01$ & 5 & $16.66 \%$ \\
\hline $13.02-14.35$ & 4 & $13.33 \%$ \\
\hline $14.36-15.69$ & 7 & $23.33 \%$ \\
\hline $15.70-17.03$ & 9 & $30 \%$ \\
\hline Jumlah & $\mathbf{3 0}$ & $\mathbf{1 0 0 \%}$ \\
\hline
\end{tabular}




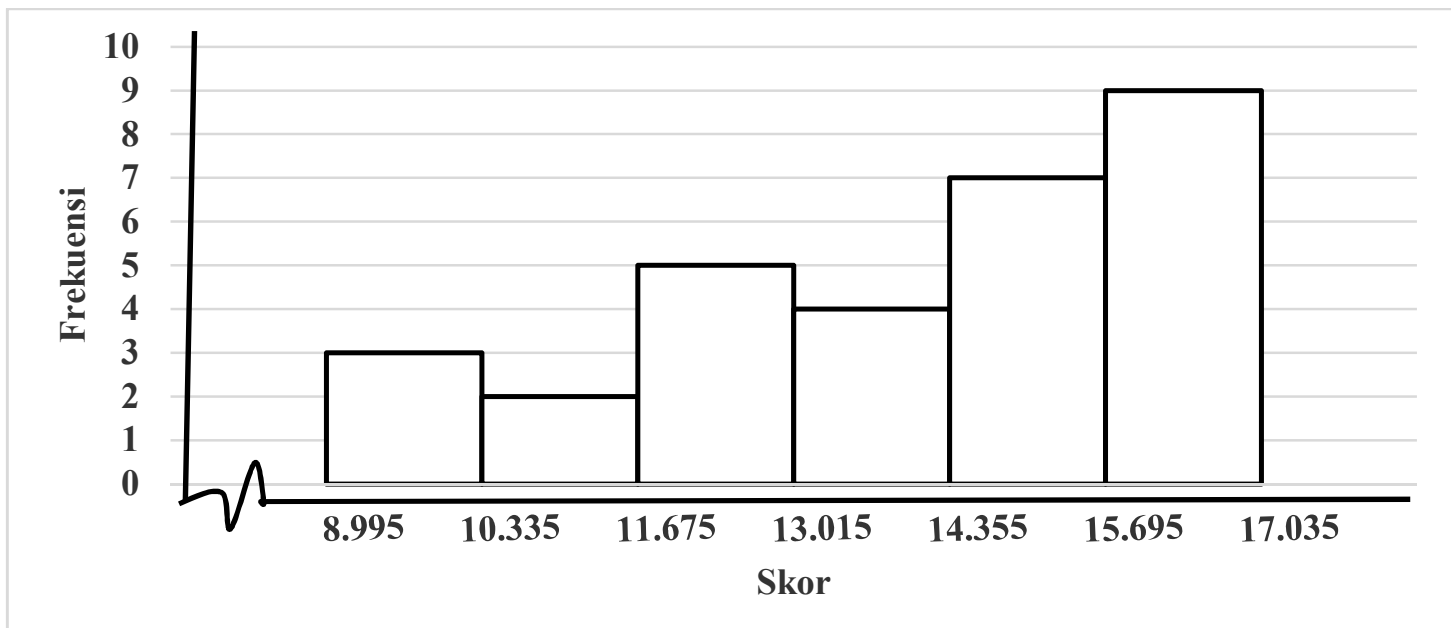

Gambar 3. Histogram Kekuatan Otot Lengan

Sebelum dilakukan pengujian hipotesis penelitian, terlebih dahulu dilakukan pengujian persyaratan analisis. Pengujian persyaratan analisis meliputi:

\section{Uji Normalitas}

Pengujian normalitas adalah suatu analisis yang dilakukan untuk menguji apakah data berasal dari populasi yang berdistribusi normal atau tidak. Pengujian ini dilakukan untuk mengetahui lebih lanjut, apakah data yang diolah dapat digunakan teknik korelasi dan regresi. Dalam hal ini pengujian normalitas data diuji dengan analisis lilliefors pada taraf signifikan $5 \%$ adalah $\mathrm{H}_{\mathrm{o}}$ : data populasi berdistribusi normal. Ha : data populasi tidak berdistribusi normal. Dasar pengambilan keputusan terhadap hipotesis normalitas adalah $\mathrm{H}_{\mathrm{o}}$ diterima jika Lo $<\mathrm{Lt}$ taraf signifikan 0.05 dan $\mathrm{H}_{\mathrm{o}}$ ditolak jika Lo $>$ Lt. Untuk rangkuman hasil uji normalitas dapat dilihat pada tabel di bawah ini.

Tabel 3. Hasil Uji Normalitas Variabel

\begin{tabular}{ccccc}
\hline No & Variabel & \multicolumn{2}{c}{ Lo $<$ Lt } & Kesimpulan \\
\hline 1 & Lay Up Shoot & 0.095 & 0.162 & Normal \\
\hline 2 & Kekuatan Otot Lengan & 0.103 & 0.162 & Normal \\
\hline
\end{tabular}

Keterangan:

Lo: Selisih harga mutlak terbesar antara peluang skor baku dengan proporsi skor baku yang lebih kecil atau dengan skor baku yang sedang dihitung.

Lt: Nilai Kritis Uji Lilliefors

Berdasarkan tabel di atas ternyata Lo $<$ Lt alpha 0.05, ini berarti bahwa distribusi data ketiga variabel normal. Dengan demikian persyaratan normalitas untuk analisis regresi dapat dipenuhi.

\section{Uji Homogenitas}

Dalam statistik uji homogenitas digunakan untuk mengetahui varian dari beberapa populasi sama atau tidak. Uji ini biasanya dilakukan sebagai prasyarat dalam analisis independen sampel T Test dan Anova. Asumsi yang mendasari dalam Analisis 
of Varians (ANOVA) adalah bahwa varian dari populasi adalah sama. Uji homogenitas digunakan sebagai bahan acuan untuk menentukan keputusan uji statistik. Adapun dasar pengambilan keputusan dalam uji homogenitas adalah: Jika nilai signifikansi $<0.05$ maka dikatakan bahwa varian dari dua atau lebih kelompok populasi data adalah tidak sama. Jika nilai signifikansi $>0.05$ maka dikatakan bahwa varian dari dua atau lebih kelompok populasi data adalah sama.

Tabel 4. Rangkuman Uji Homogenitas Variabel

\begin{tabular}{ccccc}
\hline No & Variabel X & Variabel Y & Sig $>\mathbf{0 . 0 5}$ & Kesimpulan \\
\hline 1 & Kekuatan Otot Lengan & Lay Up Shoot & 0.12 & Homogen \\
\hline
\end{tabular}

Berdasarkan tabel di atas dapat dilihat bahwa ketiga variabel X mempunyai nilai signifikan lebih besar dari 0.05 . Itu artinya bahwa data populasi penelitian mempunyai varian populasi yang sama.

\section{Uji Linearitas}

Untuk mengetahui apakah persamaan regresi bersifat linear atau tidak maka dilakukan uji $\mathrm{F}$ anava. Kriteria pengujian, jika $\mathrm{F}_{\text {hitung }}<\mathrm{F}_{\text {tabel }}$ berarti data korelasinya linear. Untuk lebih jelas dapat dilihat rangkuman pengujian linearitas pada tabel berikut ini.

Tabel 5. Rangkuman Uji Linearitas Variabel X Terhadap Y

\begin{tabular}{ccccccc}
\hline No & Variabel X & Variabel Y & $\begin{array}{c}\text { Sig }> \\
\mathbf{0 . 0 5}\end{array}$ & F $_{\text {hitung }}$ & $\mathbf{F}_{\text {tabel }}$ & Kesimpulan \\
\hline 1 & Kekuatan Otot Lengan & Lay Up Shoot & 0.44 & 1.07 & 2.48 & Linear \\
\hline
\end{tabular}

Berdasarkan tabel di atas dapat dilihat bahwa ketiga nila $\mathrm{F}_{\text {hitung }}$ yang diperoleh dari hasil analisis lebih kecil dari nilai $\mathrm{F}_{\text {tabel. }}$. Dengan demikian dapat disimpulkan hubungan antara kekuatan otot lengan dengan keterampilan lay up shoot memiliki hubungan yang linear.

Pada uji hipotesis, berdasarkan hasil analisis koefisien korelasi didapatkan $\mathrm{r}=$ 0.73 yang menyatakan besar hubungan antara variabel kekuatan otot lengan dengan keterampilan teknik dasar lay up shoot. Sedangkan kontribusi variabel kekuatan otot lengan terhadap keterampilan lay up shoot sebesar $61 \%$. Hal ini berarti bahwa, apabila siswa mempunyai kekuatan otot lengan yang prima maka akan membantunya dalam menguasai keterampilan teknik dasar lay up shoot. Untuk mengetahui hubungan fungsional antar variabel yang mana skor pada suatu variabel dapat digunakan untuk memprediksi skor pada variabel lainnya dilakukan analisis regresi linier sederhana. Dari hasil analisis diperoleh persamaan regresi $\hat{Y}=23.98+0.52$ X. Model persamaan regresi ini mengandung arti bahwa apabila kekuatan otot lengan ditingkatkan satu skor, maka kecenderungan keterampilan lay up shoot meningkat sebesar 0.52 skor pada konstanta 23.98.

\section{KESIMPULAN}

Berdasarkan analisis data dan pembahasan dalam penelitian ini, maka dapat disimpulkan sebagai berikut : Pada pengujian hipotesis menunjukkan bahwa, terdapat 
hubungan yang positif antara kekuatan otot lengan dengan keterampilan teknik dasar lay up shoot, dengan persamaan garis regresi $\hat{\mathrm{Y}}=23.98+0.52 \mathrm{X}$. Sedangkan kontribusi variabel kekuatan otot lengan terhadap keterampilan lay up shoot adalah $61 \%$.

\section{DAFTAR PUSTAKA}

Ahmadi, Nuril. 2007. Permainan Bola Basket. Surakarta: Era Intermedia.

Amber, Vic. 2013. Bolabasket. Bandung: Pionir Jaya.

Baechle, Thomas R. 2008. Essentials Strength Training Conditioning. United States Of America: Human Kinetics.

Komi, Paavo V. 2003. Strength and Power in Sport. UK: Blackwell Science Ltd.

Kosasih, Danny. 2008. Fundamental Basketball : First Step To Win. Jakarta: Karang Turi Media.

Lieberman, Nancy. 2012. Basketball For Woman. USA: Human Kinetics.

Lubis, Johansyah. 2013. Penyusunan Program Latihan. Jakarta: PT Raja Grafindo Persada.

PERBASI. 2006. Bolabasket Untuk Semua. Jakarta: Pengurus Besar PERBASI.

Sugiyono. 2008. Metode Penelitian Pendidikan. Bandung: Alfabeta.

Sukadiyanto. 2011. Pengantar Teori dan Metodologi Melatih fisik. Yogyakarta: Pendidikan Kepelatihan Olahraga FIK UNY. 